\title{
Occurrence of new species of mealybug on cotton fields in the States of Bahia and Paraíba, Brazil
}

\author{
Carlos Alberto Domingues da Silva $\left(^{*}\right)$ \\ Embrapa Algodão, Caixa Postal 174, 58428-095 Campina Grande (PB), Brasil. \\ (*) Corresponding author: carlos.domingues-silva@embrapa.br
}

Received: Jan. 7, 2012; Accepted: Oct. 13, 2012

\begin{abstract}
The cotton mealybug, Phenacoccus solenopsis Tinsley (Hemiptera: Pseudococcidae) has been reported occurring in several countries causing severe losses in economically important crops, including cotton. Based on information reported by farmers in the regions of the Southwest and Middle São Francisco, Bahia and also in the regions of the Agreste and Semi-arid of the Paraiba State, high infestations of cotton mealybugs have occurred in these regions during the cotton season of 2007 and 2008 . The cotton mealybug was identified as P. solenopsis and this represents the first record of this insect attacking cotton in Brazil.

Key words: Gossypium hirsutum, Hemiptera, Phenacoccus solenopsis, Pseudococcidae.
\end{abstract}

\section{Ocorrência de nova espécie de cochonilha em campos de algodão nos Estados da Bahia e Paraíba, Brasil}

\section{Resumo}

A cochonilha do algodão, Phenacoccus solenopsis Tinsley (Hemiptera: Pseudococcidae) tem sido registrada ocorrendo em vários países, causando perdas severas em diversas culturas de interesse econômico, incluindo o algodão. De acordo com informações relatadas por agricultores familiares do Sudoeste e Médio São Francisco, Bahia e também do Agreste e Semiárido da Paraíba, ocorreram altas infestações de cochonilhas de algodão nessas regiões durante as safras de 2007 e 2008 . 0 inseto foi identificado como P. solenopsis e representa o primeiro registro deste inseto atacando algodão no Brasil.

Palavras-chave: Gossypium hirsutum, Hemiptera, Phenacoccus solenopsis, Pseudococcidae.

The genus Phenacoccus currently contains about 180 species and is one of the largest genera in the Pseudococcidae (Ben-Dov, 1994). Cotton mealybug, Phenacoccus solenopsis Tinsley (Hemiptera: Pseudococcidae) was initially registered as a pest of cotton in Texas, United States (Fuchs et al., 1991; BEN-Dov, 2004). Since 1992, this pest has spread throughout Central America (Williams and Willink, 1992; BenDov, 2004) and it is currently found in several countries such as Brazil, Chile, China, Caribbean, Ecuador, Nigeria, Pakistan and India (Culik and Gullan, 2005; Akintola and Ande, 2008; Arif et al., 2009; NAgrare et al., 2009; WANG et al., 2009).

The cotton mealybug has a wide morphological diversity, biological adaptations and ecological adjustments that give it a high capacity to feed on different host plants, including plant species of economic importance belonging to the families Cucurbitaceae, Fabaceae and Solanaceae (Hodgson et al., 2008). In Brazil, P. solenopsis was first identified in a sample of tomato plants (Solanum lycopersicum) collected in the garden of a residence located in the city of Vitória, Espírito Santo, in October 2003 (Culik and Gullan, 2005).
In India, the biology of $P$. solenopisis was studied in the laboratory at $23-30^{\circ} \mathrm{C}$ and $49-92 \%$ relative humidity (Venilla et al., 2010). Nymphs of P. solenopsis that originated males showed longer period of development time (18.7 \pm 0.9 days) than nymphs that originated females (13.2 \pm 1.8 days), probably due to additional pupal stage of males. The durations of the first, second and third instars were 3.9, 5.1 and 4.2 days, respectively. The longevities of male and female mealybugs were 1.5 and 42.4 days, respectively. Viviparous females lay 344 nymphs in average, with the reproductive period of 30.2 days (Vennila et al., 2010).

In Brazil, there is no information on the occurrence of $P$. Solenopsis attacking cotton (Gossypium hirsutum L.), although high infestations of scale insects have been verified in cotton crop located in the Paraíba State (Patos, Sáo João do Rio do Peixe, Campina Grande, Itaporanga and Choró), Ceará State (Barbalha and Missão Velha) (BAstos et al., 2007) and Bahia State (Middle and South regions of São Francisco River and Guanambí). 
Specimens of the mealybug collected in cotton fields with 120 days of age in the countries of Candiba, Iuiu, Licinio de Almeida, Malhada, Palmas de Monte Alto, Pindaí and Urandi, State of Bahia and in the cities of Campina Grande and Patos, State of Paraiba, from 13 to 17 May 2009, were identified as P. solenopsis Tinsley (Hemiptera: Pseudococcidae) by Dr. Penny J. Gullan (University of California, Davis, USA). This species is deposited in the collection of the Bohart Museum of Entomology at the same university.

The species $P$. solenopsis present multilocular ventral pore usually on segments VI and VII to the VIII, absence of quinquelocular pores and dorsal multilocular pores or oral collar tubular ducts, usually with nine antennal segments, presence of circulus usually large and flaccid, translucent pores at the apex of the femur and tibia and denticle on claw (Cox, 1989; MCKenzie, 1967; Hodgson et al., 2008) (Figure 1). In the field, $P$. solenopsis can be identified by displaying the oval body about five millimeters in length, color ranging from dark green to almost black, red legs, covered by a thin layer of white wax, mealy, with 18 pairs of waxy filaments short and medium-sized around the body and anal filaments with about one quarter the length of the body and two dark stripes on both sides of the border in the middle of the body, which form a pair of dark longitudinal lines on the back (TANWAR et al., 2011) (Figure 1). These morphological characteristics differ considerably from species Planococcus minor Maskel (Hemiptera: Pseudococcidae) described by Bastos et al. (2007) attacking different locations of cotton crop. Specimens of the genus Planococcus differs from Phenacoccus to present all dorsal setae flagellate, even if minutely short (Williams and Willink, 1992) and is devoid of a pair of horizontal dark stripes at the tip of the end of the body.

Among several cotton fields sampled in the State of Bahia, thirteen showed evidence of mealybug infestations and only one cotton field had a high infestation. Also, we found several dead plants distributed in the cotton fields (Figure 2). In the Paraíba State, all cotton farms sampled showed high mealybug infestations. The infestation of $P$. solenopsis in the cotton plants begins in sites where the metabolism is accelerated (terminal bud, based buttons and flowers) (Figure 2). It can attach a generalized way all parts of the plants if control measures are not adopted. Their feeding causes yellowing of leaves, defoliation, reduced growth and death of plants and can serve indirectly as vectors of pathogens (CuLIK and GULAN, 2005). In addition, the production of honeydew contributes to the development of sooty mold that reduces photosynthesis and may harm the marketing

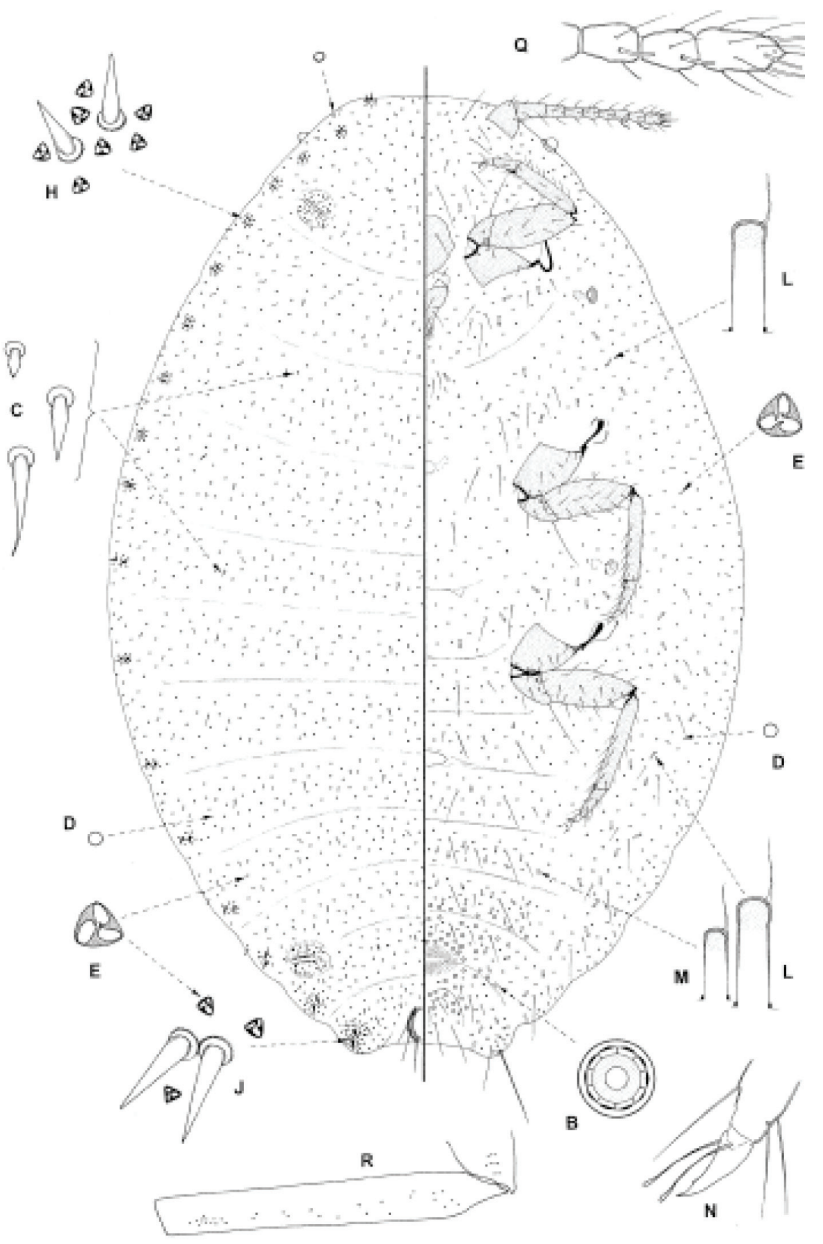

Figure 1. Schematic representation of the adult female of Phenacoccus solenopsis Tinsley (Hemiptera: Pseudococcidae). Reprinted from Hodgson et al (2008). Type material from New Mexico, USA. B: multilocular disc pore; C: dorsal lanceolate setae; D: simple (discoidal) pore; E: trilocular pore; $\mathrm{H}$ : spinose setae on more posterior cerarii; J: cerarius C18; L: large oral collar tubular duct; M: small oral collar tubular duct; $\mathrm{N}$ : claw.

of production (ARIF et al., 2012). In the region of Guanambi, State of Bahia, the most severe attacks of mealybug $P$. solenopsis in cotton crops were observed at the beginning of cultivation, after the first rains and the appearance of leaves (late November and early December), while in Paraíba State, these attacks were recorded at the end of the cycle of growing cotton in the periods of low rainfall and high temperatures (between late August and late November). Therefore, the occurrence of mealybug pests of cotton seems to be related to long periods of drought, followed by short periods of high water availability.

In this paper we reported the first record of P. solenopsis attacking cotton in Brazil. Due the damage caused on the cotton plants, we highlight the need to develop studies for the management of this pest. 

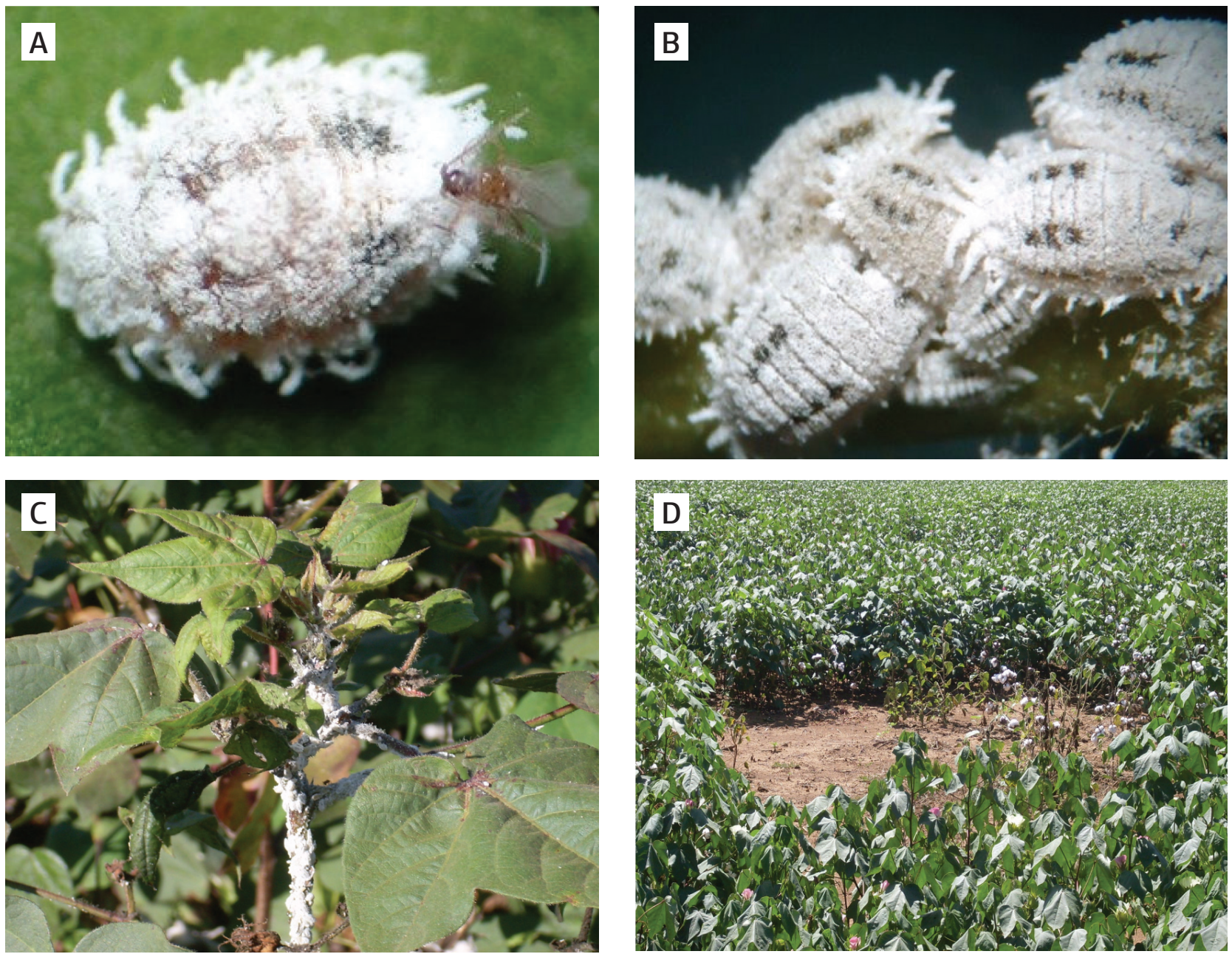

Figure 2. Female and male (a) and colony (b) of Phenacoccus solenopsis mealybug; attack of nymphs and adults of the mealybug in the apical region of plant (c) and on cotton crop (d). Photo: C.A.D. Silva

\section{ACKNOWLEDGEMENTS}

To Penny J. Gullan, Professor of Entomology at the University of California, Davis, United States, to Conselho Nacional de Desenvolvimento Científico e Tecnológico (CNPq), and to Fundo para o Desenvolvimento do Agronegócio do Algodáo (Fundeagro), for financial support.

\section{REFERENCES}

AKINTOLA, A.J.; ANDE, A.T. First record of Phenacoccus solenopsis Tinsley (Hemiptera: Pseudococcidae) on Hibiscus rosa-sinensis in Nigeria. Agricultural Journal, v.3, p.1-3, 2008.

ARIF, M.I.; RAFIQ, M.; GHAFFAR, A. Host plants of cotton mealybug (Phenacoccus solenopsis): a new menace to cotton agroecosystem of Punjab, Pakistan. International Journal of Agriculture and Biology, v.11, p.163-167, 2009.
ARIF, M.I.; RAFIQ, M.; WAZIR, S.; MEHMOOD, N.; GHAFFAR, A. Studies on cotton mealybug, Phenacoccus solenopsis (Pseudococcidae: Homoptera), and its natural enemies in Punjab, Pakistan. International Journal of Agriculture and Biology, v.14, p.557-562, 2012.

BASTOS, C.S.; ALMEIDA, R.P.; VIDAL NETO, F.C.; ARAÚJO, G.P. Ocorrência de Planococcus minor Maskell (Hemiptera: Pseudococcidae) em algodoeiro no nordeste do Brasil. Neotropical Entomology, v.36, p.625-628, 2007.

BEN-DOV, Y.A. Systematic catalogue of the mealybugs of the world (Insecta: Homoptera: Coccoidea: Pseudococcidae and Putoidae). Andover: Intercept, 1994. 686p.

BEN-DOV, Y. Scalet Net, Phenacoccus solenopsis, 2004. Available from: http://198.77.169.79/ catalogs/pseudoco/ Phenacoccussolenopsis.htm. Acessed: October 6, 2010.

COX, J.M. The mealybug genus Planococcus (Homoptera: Pseudococcidae). Bulletin of the Natural History Museum Entomology, v.58, p.1-78, 1989. 
CULIK, M.P.; GULLAN, P.J. A new pest of tomato and other records of mealybugs (Hemipreta: Pseudococcidae) from Espírito Santo, Brazil. Zootaxa, v.964, p.1-8, 2005.

FUCHS, T.W.; STEWART, J.W.; MINZENMAYER, R.; ROSE, M. First record of Phenacoccus solenopsis Tinsley in cultivated cotton in the United States. Southwestern Entomologist, v.16, p.215-221, 1991.

HODGSON, C.; ABBAS, G.; ARIF, M.J.; SAEED, S.; KARAR, H. Phenacoccus solenopsis Tinsley (Sternorrhyncha: Coccoidea: Pseudococcidae), an invasive mealybug damaging cotton in Pakistan and India, with a discussion on seasonal morphological variation. Zootaxa, v.1913, p.1-35, 2008

MCKENZIE, H.L. Mealybugs of California with taxonomy, biology, and control of North American species (Homoptera: Coccoidea: Pseudococcidae). Berkeley: University of California Press, 1967.526 p.

NAGRARE, V.S.; KRANTHI, S; BIRADAR, V.K.; ZADE, N.N.; SANGODE, V.; KAKDE, G.; SHUKLA, R.M.; SHIRAVE, D.;
KHADI, B.M.; KRANTHI, K.R. Widespread infestation of the exotic mealybugs species, Phenacoccus solenopsis Tinsley (Hemiptera: Pseudococcidae) on cotton in India. Bulletin of Entomological Research, v.1, p.1-5, 2009.

TANWAR, R.K.; JEYAKUMAR, P.; SINGH, A.; JAFRI, A.A.; BAMBAWALE, O.M. Survey for cotton mealybug, Phenacoccus solenopsis (Tinsley) and its natural enemies. Journal of Environmental Biology, v.32, p.381-384, 2011.

VENNILA, S.; DESHMUKH, A.J.; PINJARKAR, D; AGARWAL, M.; RAMAMURTHY, V.V.; JOSHI, S.; KRANTHI, K.R.; BAMBAWALE, O.M. Biology of the mealybug, Phenacoccus solenopsis on cotton in the laboratory. Journal of Insect Science, v. 10, p.1-7, 2010.

WANG, Y.P.; WU, S.A.; ZHANG, R.Z. Pest risk analysis of a new invasive pest, Phenacoccus solenopsis, to China. Chinese Bulletin of Entomology, v.46, p.101-106, 2009.

WILLIAMS, D.J.; WILLINK, M.C.G. de. Mealybugs of Central and South America. Wallingford, C.A.B. International, 1992. 635p. 